\title{
A review on newer techniques in extraction of oleaginous flaxseed constituents
}

\author{
Mayuri Sharma, Kritika Dadhwal, Yogesh Gat*, Vikas Kumar, Anil Panghal, Rasane Prasad, \\ Sawinder Kaur and Punam Gat \\ Department of Food Technology and Nutrition, Lovely Professional University, 144411 Phagwara, India
}

Received 1 October 2018 - Accepted 18 February 2019

\begin{abstract}
Flaxseed is the chief oilseed crop that is grown in many regions of the world for medicinal and nutritional purposes. It has been used for oil and fiber since centuries. Flaxseed has an enormous role in functional foods for its nutritional and pharmaceutical values. Among the various components of flaxseed lignans, phenolic acids, proteins and oil are of the main interest. Oil and lignans have prime concentrations in the flaxseed. To study the extraction of these compounds, various extraction methods have been investigated. Oil has been extracted by mechanical pressing in ancient times but presently new techniques have been developed. These include microwave assisted extraction, supercritical $\mathrm{CO}_{2}$ extraction, ultrasonic assisted extraction, etc. Enzymes are also gaining importance in the extraction of oil, lignan and proteins as they give more yield of compounds and easily degrade the cell wall of the flaxseed. The need of these novel techniques lies in the fact that traditional methods have different shortcomings like low yield, more time, more energy and less environmental friendly. This review put on a view to different techniques which have been investigated for the extraction of different components of flaxseed. Quality evaluation and comparison of flaxseed oils and other bioactive components obtained by newer techniques with those produced by conventional extraction methods is also reported.
\end{abstract}

Keywords: flaxseed / nutritional composition / newer extraction techniques / oleaginous plant constituents

Résumé - Une revue des nouvelles techniques d'extraction des constituants des graines de lin oléagineux. La graine de lin est la principale culture de graines oléagineuses qui est cultivée dans de nombreuses régions du monde à des fins médicinales et nutritionnelles. Le lin a été utilisé pour l'huile et la fibre depuis des siècles. La graine de lin joue un rôle important dans les aliments fonctionnels en raison de ses valeurs nutritionnelles et pharmaceutiques. Parmi les divers composants des graines de lin, les lignanes, les acides phénoliques, les protéines et l'huile sont particulièrement intéressants. L'huile et les lignanes ont des concentrations majeures dans les graines de lin. Pour étudier l'extraction de ces composés, différentes méthodes d'extraction ont été étudiées. L'huile était extraite par pressage mécanique dans les temps anciens, mais de nouvelles techniques ont depuis été développées. Celles-ci incluent l'extraction assistée par microondes, l'extraction au $\mathrm{CO}_{2}$ supercritique, l'extraction assistée par ultrasons, etc. Les enzymes gagnent également en importance dans l'extraction de l'huile, des lignanes et des protéines car elles offrent davantage de rendement en composés et dégradent facilement la paroi cellulaire de la graine de lin. La nécessité de ces nouvelles techniques réside dans le fait que les méthodes traditionnelles présentent différents inconvénients : un faible rendement, plus de temps, plus d'énergie et un moindre respect de l'environnement. Cette revue liste différentes techniques qui ont été étudiées pour l'extraction de différents composants de la graine de lin. L'évaluation de la qualité et la comparaison des huiles de lin et d'autres composants bioactifs obtenus par des techniques plus récentes avec celles produites par des méthodes d'extraction classiques sont également rapportées.

Mots clés : graine de lin / composition nutritionnelle / nouvelles techniques d'extraction / composants des plantes oléagineuses

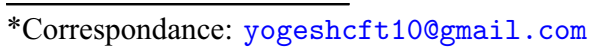




\section{Introduction}

Flaxseed also called linseed (Linum usitatissimum) is a major oilseed crop belonging to Lineaceae family. Flax grows in various regions of the world such as India, Argentina, America, China, Canada, etc. Among these countries, the world's largest exporter of flaxseed is Canada accounting for $75 \%$ of global flaxseed trade and also produces $40 \%$ of entire world's flaxseed (Pradhan et al., 2009). Flaxseed is a nutrition booster and plays an important role in increasing the quality of food (Marpalle et al., 2014). A studies suggested that addition of roasted flaxseed in bread led to increase in the calorie content, low glycemic index and high antioxidant activity (Marpalle et al., 2015). Every part of the plant can either be used directly or can be utilized in processed form. The stem of flax contains the best quality fiber having strength and durability. Flaxseed is also rich in its nutritional value. The seeds of flax are rich in oil having omega-3 fatty acids, proteins and lignans (Singh et al., 2011). Flaxseed constitutes $40-45 \%$ lipids, 20-25\% protein, 20-25\% fiber and 1\% lignans (Tirgar et al., 2016). The flaxseed is mainly utilized for the industrial purposes such as manufacturing of paint, inks, cosmetic products and varnishes. Flaxseed is the main focus of the researchers due to its various health benefits by its prime biological active components such as alpha-linolenic acid, lignan-secoisolariciresinol diglycoside (SDG) and dietary fibers (Touré and Xueming, 2010). In last few decades flaxseed, an underutilized oilseed has gained importance as functional foods due to its unique nutrient profile (Kaur et al., 2017). The increased health concerns of saturated fats have led to the utilization of omega-3 polyunsaturated acids (Khattab and Zeitoun, 2013). Flaxseed oil possess increased amount of polyunsaturated fatty acids and less saturated fatty acids. However, this property also makes it receptive to the oxidative rancidity that reduces the shelf life of flaxseed oil. Therefore, flax oil is not preferred for cooking (Malcolmson et al., 2000). Flaxseed is rich in lignans among which SDG is the main lignan and possess health benefits (Kaur et al., 2018). It has anti-carcinogenic and antioxidant effects. With the action of bacterial flora, it gets digested in the colon to produce mammalian lignans and protects the human from breast and prostate cancer (Zhang and $\mathrm{Xu}, 2007$ ). Flaxseed proteins are useful for the immune system. They are rich in arginine and glutamine, so the keep the heart healthy. Flaxseed proteins also have a fungistatic effect against the plant and human pathogens (Tehrani et al., 2014). Due to these potential health benefits of different flaxseed components, there is a necessity for the development of innovative extraction techniques. Various methods like phase extraction, enzyme-assisted extractions and supercritical extraction are in practice. The newer techniques should give high yield, consume less energy and time and be eco-friendly with less use of the chemicals. Traditional methods used for extraction were time and energy consuming. Due to the use of different solvents, there were high risks of different health hazards. This review summarizes different novel techniques which can be used as an alternative to conventional methods. The different techniques opted for extraction of oil, lignans, phenolic acids and protein are reported.

\section{Nutritional composition}

Among all the functional foods, flaxseed is a great source of ALA, lignans, proteins and phenolic compounds (Oomah, 2001). Growing environment and genetic conditions decide the chemical composition of flaxseed. Flaxseed is rich in oil content which contributes about $98 \%$ triacylglycerol, phospholipids and $0.1 \%$ of fatty acids (Kajla et al., 2015). Flaxseed contains $20-25 \%$ proteins. Globulin (58-66\%) and albumin $(20-42 \%)$ constitutes the major protein fractions (Rabetafika et al., 2011). Flaxseed contains high amount of lignans (phytoestrogens) and phenolic compounds. The major lignan present in flaxseed is secoisolariciresinol diglycoside (SDG) which accounts for 77 to $209 \mathrm{mg} \mathrm{SDG} / \mathrm{tbsp}$ of whole flaxseed (Morris, 2007). SDG is 11.7 to $24.1 \mathrm{mg} / \mathrm{g}$ and 6.1 to $13.3 \mathrm{mg} / \mathrm{g}$ in defatted and whole seed flour respectively. Flaxseeds also contain anti-nutrients that cause adverse influence on the health of human beings. Cyanogenic glycosides are the major anti-nutrients and are fractionated into linustatin $(213-352 \mathrm{mg} /$ $100 \mathrm{~g})$, neolinustatin $(91-203 \mathrm{mg} / 100 \mathrm{~g})$ and linmarin $(32 \mathrm{mg} /$ $100 \mathrm{~g}$ ). The content of these three glycosides depend upon cultivar and location. Phytic acid is another anti-nutrient present in flaxseed that ranges from 23 to $33 \mathrm{~g} / \mathrm{kg}$ of the flaxseed meal. Phytic acid hinders the absorption of calcium, copper, magnesium, etc. The presence of trypsin inhibitors is also reported in flaxseeds. Flaxseed have a unique place among the oilseeds because of the presence of mucilage located in outer layers of the seed (Singh et al., 2011). Flaxseed mucilage has many health benefits and potential functional properties. Flaxseed mucilage increases the viscosity of intestinal contents and delays gastric emptying and nutrient absorption (Kajla et al., 2015). Flaxseed has large amount of phenolic acids that is $800-1000 \mathrm{mg}$ per $100 \mathrm{~g}$ of the seeds (Herchi et al., 2014). The main phenolic acids that are present in defatted sample of the flaxseed are gallic acid $(2.8 \mathrm{mg} / \mathrm{g})$, chlorogenic acid $(7.5 \mathrm{mg} / \mathrm{g})$ and ferulic acid $(10.9 \mathrm{mg} / \mathrm{g})$. Other phenolics are present in very less quantities which includes p-coumaric acid glucosides, hydroxycinnamic acid glucosides and 4-hydroxybenzoic acid. Flaxseed is a great source of minerals mainly potassium $(650 \mathrm{mg} / 100 \mathrm{~g})$, magnesium $(350-431 \mathrm{mg} / 100 \mathrm{~g})$ and calcium (236-250 mg/100 g) (Morris, 2007).

\section{Different techniques for the extraction of the flaxseed oil}

Extraction of oils from oilseeds is a key step for their commercialization. The extraction process directly affects the quantity and quality of oils. Traditionally, oil is extracted by mechanical screw pressing or by solvent extraction using hexane, involves enormous construction and operational costs. The conventional techniques of solvent extraction give a dark coloured meal which is thought to be due to the interaction of the protein with polyphenols. It is envisaged that the new extraction technologies would not only allow complete utilization of flaxseed but also give a quality product. The traditional methods are time and energy consuming, associated with high safety hazard, greater energy input, inferior quality oil, low quality meal, environmental risk and toxicological effects. All these drawbacks associated with hexane-extraction have urged the edible oil industry to seek alternative 
Table 1. Different techniques for the extraction of oil from flaxseed.

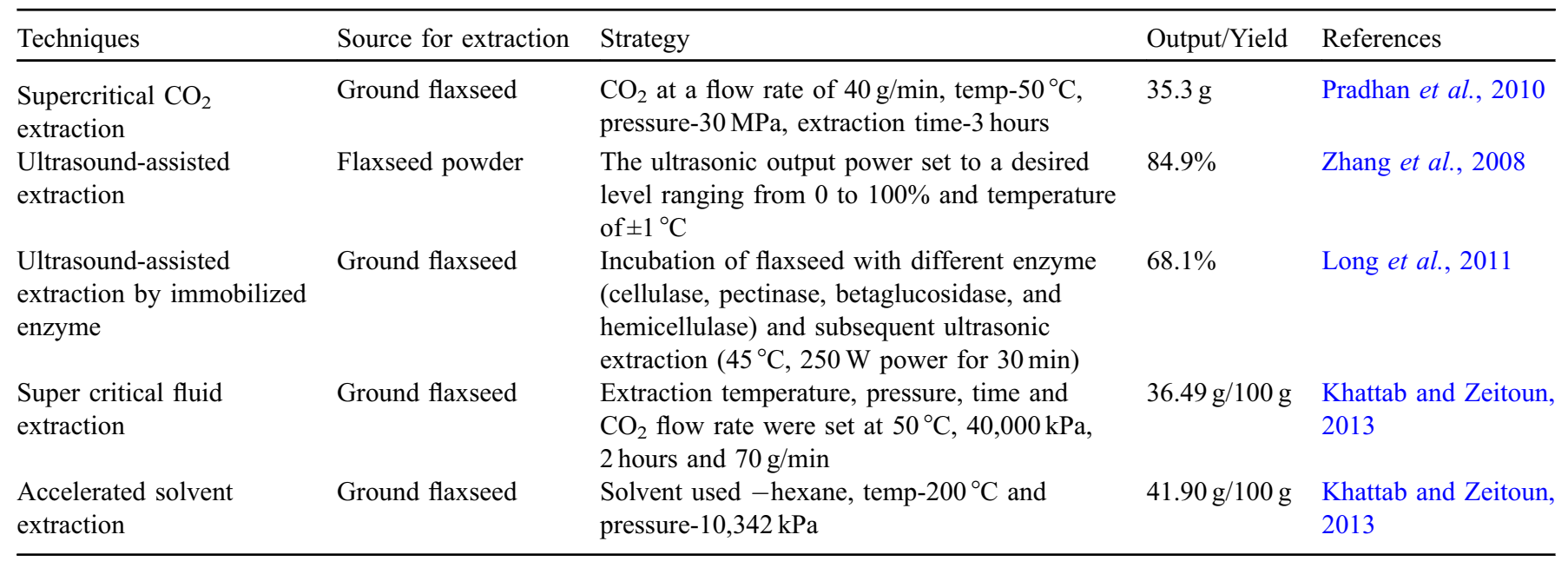

techniques for extraction of oils which are suitable and environment friendly. Flaxseed oil is commonly utilized as nutraceutical due to the presence of polyunsaturated fatty acids. Existence of omega-3 fatty acids in oil increases its nutritional value. Flaxseed oil is also utilized for various industrial purposes such as for the manufacturing of varnishes, paints, cosmetic products, putty and finishing of wood. Flaxseed oil can be extracted from various techniques. Table 1 represents the different techniques that are used for the extrication of oil from flaxseeds.

\subsection{Supercritical fluid $\mathrm{CO}_{2}$-extraction}

Pradhan et al. (2010) reported that supercritical fluid $\mathrm{CO}_{2}-$ extracted flaxseed oil is superior in terms of yield of $\omega$-6-fatty acid and $\omega$-3-fatty acid as compared to soxhlet and screw press techniques. The composition of oil extracted from SFE was almost same as compared to screw press. However, the yield of fatty oil was comparatively less $(27.8 \%)$. Supercritical fluid $\mathrm{CO}_{2}$-extraction is an ecofriendly process and the extracted oil is of higher quality without any solvent residue. Hence, it can be used preferably in different food products. Khattab and Zeitoun (2013) compared the oil that was extracted from accelerated solvent extraction (ASE), super critical fluid extraction (SFE), and solvent extraction (SE). It was reported that oil yield was high in case of SE and ASE as compared to SFE. However, supercritical fluid $\mathrm{CO}_{2}$-extracted oil has higher SDG contents, phenolics and PUFAs.

\subsection{Ultrasonic assisted extraction (UAE)}

Zhang et al. (2008) reported the use of ultrasonic assisted extraction of flaxseed oil. The reports suggested that by using UAE there was increase in the oil yield along with low solvent consumption and significant decrease in the extraction time. Long et al. (2011) used ultrasound extraction assisted with an aqueous enzymatic process (AEP-UE) for the extraction of flaxseed oil. About $68.1 \%$ of oil was extracted with the help of this technique. The oil extracted by AEP-UE has $1.5 \%$ more unsaturated fatty acids as compared to organic solvent extraction technique. This technique can be potentially applied in oil industry as it is an ecofriendly technology as compared to solvent extraction technique.

\subsection{Three-phase partitioning (TPP)}

Tan et al. (2016) reported that enzyme-assisted three-phase partitioning method can be used for the extraction of flaxseed oil. The entire procedure was divided into two parts: firstly the enzymolyisis in which flaxseed was hydrolysed with enzymes and secondly, three-phase partitioning (TPP) for extraction of flaxseed oil. The results suggested that this technique gives higher yield of oil and quality as compared to other techniques. It has potential to be utilized for large or pilot scale production of flaxseed oil.

\subsection{Subcritical extraction}

Subcritical extraction is based on the technique of using a solvent as an extractant. Piva et al. (2018) used subcritical propane for the extraction of flaxseed oil. Propane is preffered as solvent as it has high solvation properties and is non-toxic. The use of propane led to yeild enchancement and the quality of the brown flaxseed oil was better as compared to mechanical extraction. The oil extracted by this technique showed that the free fatty acid content is less as compared to commercial oil $(0.95 \%$ wt vs $1.37 \% \mathrm{wt})$.

\section{Different techniques for extraction of lignans and phenolic acids}

A number of studies have been undertaken on the antioxidant potential of flaxseed and on its phenolic compounds. Different phenolics present in flaxseed are lignans, phenolic acids, flavonoids, Phenylpropanoid glucoside and tannins. Flaxseed (Linum usitatissimum) is the major natural source of lignan with secoisolariciresinol diglucoside 
Table 2. Different techniques for the extraction of lignans and phenolic acids.

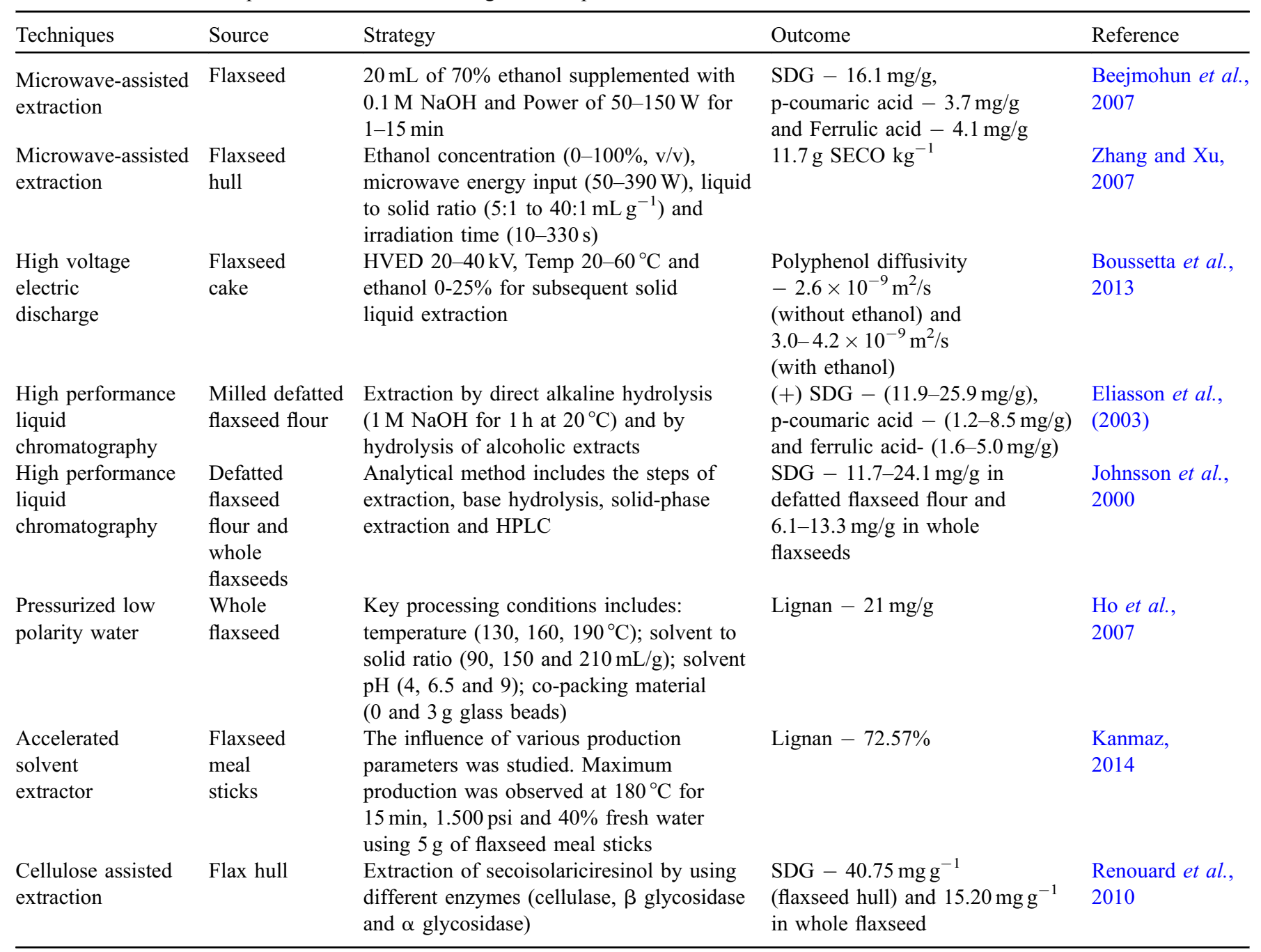

being the main lignan compound. Lignans are configured by the joining of two cinnamic acid residues and a 2,3dibenzylbutane nucleus (Cacace and Mazza, 2006). The phenolic acids which are present in large concentration in flaxseed are ferulic acid and p-coumaric acid. There is rise in the intrest on SDG because of its different potential health benefits like anticarcinigenic, estrogenic and other antioxidant properties (Zhang et al., 2007). Thus, there is a need for development of novel approach for efficient extrication of these compounds. Table 2 put on the view of different techniques used for the extraction of phenols.

\subsection{Microwave-assisted technique (MAE)}

Beejmohun et al. (2007) for the first time put on an application of microwave assisted technique for the extraction of SDS, p-coumaric acid and ferulic acid. The comparison was also carried out with the conventional extraction techniques used for the extraction of these compounds. The SDS, pcoumaric acid and ferulic acid content found was $16.1 \mathrm{mg} / \mathrm{g}$, $3.7 \mathrm{mg} / \mathrm{g}, 4.1 \mathrm{mg} / \mathrm{g}$ on subjecting the sample to three-minute
MAE. Microwave-assisted extraction produced greater amount of phenolic compounds in comparison with other methods in short duration of time. Zhang et al. (2007) executed microwave-assisted extraction of secoisolariciresinol diglucoside (SDG) from flaxseed hull. The MAE extraction technique was also compared to stirring extraction and soxhlet extraction techniques. The comparison of three techniques brought out to a conclusion that the yield of SDG by microwave-assisted extraction was greater $\left(11.7 \mathrm{~g} \mathrm{SECO} \mathrm{kg}^{-1} \mathrm{DFH}\right)$ as compared to stirring technique $\left(10.0 \mathrm{~g} \mathrm{SECO} \mathrm{kg}^{-1} \mathrm{DFH}\right)$, however, less

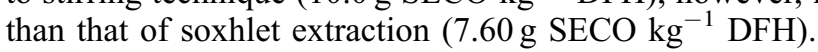

\subsection{High voltage electric diffusion (HVED)}

Boussetta et al. (2013) described the effect of high voltage electric, mild temperature treatment and concentration of ethanol on the yield of lignans and polyphenols from flaxseed cake. HVED helps in the rupturing of plant tissues and thereby releasing the intracellular compounds. The results suggested that the presence of ethanol shows a synergic effect in the extrication of polyphenols in both crushed and uncrushed 
Table 3. Different techniques for the extraction of proteins.

\begin{tabular}{|c|c|c|c|}
\hline Techniques & Source & Yeild & References \\
\hline $\begin{array}{l}\text { Pressurized low } \\
\text { polarity water }\end{array}$ & $\begin{array}{l}\text { Defatted } \\
\text { flaxseed meal }\end{array}$ & $33.31 \mathrm{~g} / 100 \mathrm{~g}$ & Ho et al., 2007 \\
\hline $\begin{array}{l}\text { Enzyme assisted } \\
\text { solvent extraction }\end{array}$ & $\begin{array}{l}\text { Flaxseed } \\
\text { meal }\end{array}$ & $86.80 \%$ & Tirgar et al., 2017 \\
\hline $\begin{array}{l}\text { Enzyme assisted } \\
\text { extraction }\end{array}$ & $\begin{array}{l}\text { Flaxseed } \\
\text { meal }\end{array}$ & $65.08 \%$ & Tirgar et al., 2017 \\
\hline $\begin{array}{l}\text { Alkali isoelectric } \\
\text { precipitation }\end{array}$ & $\begin{array}{l}\text { Flaxseed } \\
\text { meal }\end{array}$ & $51.5 \%$ & Tirgar et al., 2017 \\
\hline
\end{tabular}

flaxseed cake. The diffusion of polyphenols from HVED treated sample was found to be $2.6-2.7 \times 10^{-9} \mathrm{~m}^{2} / \mathrm{s}$ (without ethanol) and $3.0-4.2 \times 10^{-9} \mathrm{~m}^{2} / \mathrm{s}$ (with ethanol). The yield of lignan was found to be comparitively less than that found in literature. This technique is not as effective as alkaline or acid hydrolysis but it can be presumed that a combination of these techniques could create a new opportunity to reduce the application of chemicals and accelerate the solid-liquid separation step.

\subsection{High-performance liquid chromatography}

Eliasson et al. (2003) studied the high performance liquid chromatographic analysis (HPLC) of hydroxycinnamic acid glucosides and secoisolariciresinol diglucoside (SDG) in milled defatted flaxseed flour. The extraction was brought about by two methods; one was with dioxane-ethanol succeeded by the alkaline hydrolysis and other was extraction by direct alkaline hydrolysis. The results exhibit that yield was higher in the case of direct alkaline hydrolysis. The hydroxycinnamic acid glucosides and SDG were determined. Results suggested that a lot of variation was found in the phenolic glycosides and SDG content in Swedish flaxseed samples. Johnsson et al. (2000) carried out high performance liquid chromatography for the analysis secoisolariciresinol diglucoside. The analytical method included the steps of extraction, base hydrolysis, solid-phase extraction, and high performance liquid chromatography. Studies on the changes in SDG content were carried out in 15 cultivars of Sweden and Denmark flaxseed samples. The results suggested that the content varied from 6.1 and $13.3 \mathrm{mg} / \mathrm{g}$ (whole flaxseeds) and 11.7 and $24.1 \mathrm{mg} / \mathrm{g}$ in (defatted flaxseed flour).

\subsection{Pressurized low polarity water extraction}

Pressurized low polarity water extraction was used for extraction of lignans and bioactive compounds from the whole flaxseed. The effect of different process conditions like optimum flow rate, temperature, and total volume were studied to extract the selected polyphenols. The results concluded that the maximum amount of lignan and bioactive compounds are produced at $160^{\circ} \mathrm{C}$ and $5.2 \mathrm{MPa}$. However, on dry basis, it takes place at $140{ }^{\circ} \mathrm{C}$ and $5.2 \mathrm{MPa}$. The flow rate of $0.5 \mathrm{~mL} / \mathrm{min}$ is suitable for extraction of secoisolariciresinol diglucoside (SDG) and flow volume of $30-40 \mathrm{~mL} / \mathrm{g}$ is needed for maximum retrieval. Bed depth to ID ratios of 5-18 led to maximum yield that is $90-95 \%$. This technique is reported to be superior to other techniques because it is cost effective, less time consuming, higher recovery, less use of energy and raw material (Cacace and Mazza, 2006).

\subsection{Enzyme-assisted extraction}

Puri et al. (2012) stated that enzymes enhances the production of bioactive compounds from the plant source. The enzymes such as cellulases, pectinases and hemicellulases are competent of rupturing the plant cell wall which result in more yeild of the bioactive compounds from the plants. The enzymes increase the cell wall permeability by hydrolyzing the cell wall component and result in high extraction. Renouard et al. (2010) brought about the production of secoisolariciresinol from whole flaxseed and flaxseed hull. Enzymes are very productive for the recovery of variety of compounds from the flaxseed. The enzymes used were cellulase and bglucosidase. Cellulase enzyme R10 from Trichoderma reesei proved out to be better than b-glucosidase enzyme. Under optimum conditions, the maximum yield of secoisolariciresinol was found out to be $40.75 \mathrm{mg} \mathrm{g}^{-1}$ in hulls of cv. Baladin and in whole seeds of cv. Barbara, it was found out to be $15.20 \mathrm{mg} \mathrm{g}^{-1}$. The recovery was higher as compared to the papers which are published previously. This is an efficient method to recover valuable yield of SECO for in vitro and vivo experiments.

\subsection{Ionic liquid-based ultrasonic assisted extraction}

Tan et al. (2015) carried out ionic liquid-based ultrasonic assisted extraction of SDG which was futher purified by onic liquid-based aqueous two-phase system (IL-ATPS). These techniques are suggested to be effective for extraction of SDG and bioactive components of plants. The efficiency of extraction was found out to be $93.35 \%$ under optimum conditions of $\mathrm{pH}(11)$, temperature $\left(22^{\circ} \mathrm{C}\right), \operatorname{IL}(45.86 \%)$ and $\mathrm{Na}_{2} \mathrm{SO}_{4}(8.27 \%)$.

\section{Different techniques for extraction of proteins}

The flaxseeds are an efficient source of proteins. The proteins are of prime importance as they help in the reduction of hypertension and heart diseases because the plant proteins tend to reduce the cholesterol levels. The type of extraction process affects the quality of protein. There are different techniques which can be used to extract the protein from plant source. Table 3 shows the various techniques for the extraction of proteins from the flaxseed.

\subsection{Pressurized low polarity water technique}

Ho et al. (2006) used pressurized low polarity water technique for the extraction of proteins, lignans and carbohydrates from the defatted flaxseed meal. Several conditions like temperature, $\mathrm{pH}$, solvent to solid ratio and introduction of co-packaging material for optimal recovery of bioactive compounds were also analyzed. The ideal conditions 
required for the production of proteins were $160{ }^{\circ} \mathrm{C}, \mathrm{pH} 9$ and solvent to solid ratio is $210 \mathrm{~mL} / \mathrm{g}$ meal. The temperature recommended for the isolation of carbohydrates and protein was $130-160^{\circ} \mathrm{C}$ as they are highly potent to thermal decomposition. Pressurized low polarity water technique has an ability to be a commercially effective technique for extraction of proteins.

\subsection{Enzyme-assisted extraction}

Tirgar et al. (2016) investigated the effect of extraction method on the flaxseed protein concentrates (from cold pressed flaxseed meal). The extraction techniques used were an enzyme-assisted, alkali isoelectric precipitation and enzyme solvent assisted. The comparison was also carried out with pea protein concentrates. The yields of proteins by enzymeassisted solvent extraction $(86.80 \%)$ were compared to enzyme-assisted $(65.08 \%)$ and alkali isoelectric precipitation $(51.5 \%)$. The results also suggested that though the protein yield was less in alkali-extracted flaxseed protein concentrate but it had highest emulsifying properties as compared to other two extraction methods. The study recommended the use of alkali- and enzymatic-extraction techniques for the emulsion based foods that require good emulsifying properties. Enzymeassisted solvent extraction can be used to produce protein for a food system. Thus, these extraction techniques can be used to produce proteins with specific functional properties.

\section{Conclusion}

Different types of extraction methods have been used to extract oil, lignans, phenolic acids and proteins. Traditional methods like mechanical pressing and soxhlet have many limitations. Hence, there is a need to explore new techniques for the extraction of different biologically active components. Among the newer techniques, enzymes-assisted three-phase partitioning and ultrasound extractions are giving more yield and are fast processes. Pressurized low polarity extraction and microwave-assisted extraction are giving more yield of lignans and phenolic acids. For the extraction of proteins, enzymatic extraction is giving better yield and having less limitations as compared to other methods. Cost savings, environmental and safety concerns, and nutrition issues seem to be achievable by the successful development of alternative techniques for conventional oil extraction techniques.

\section{Conflict of interest} interest.

Authors declare that they do not have any conflict of

Acknowledgements. We would like to acknowledge Lovely Professional University for providing equipments and their support for carrying out the research work.

\section{References}

Beejmohun V, Fliniaux O, Grand E, Lamblin F, Bensaddek L, Christen P, Kovensky J, Fliniaux M.A, Mesnard F. 2007. Microwave-assisted extraction of the main phenolic compounds in flaxseed. Phytochem Anal 18(4): 275-282. [CrossRef] [Google Scholar].

Boussetta N, Turk M, De Taeye C, Larondelle Y, Lanoisellé JL, Vorobiev E. 2013. Effect of high voltage electrical discharges, heating and ethanol concentration on the extraction of total polyphenols and lignans from flaxseed cake. Ind Crop Prod 49: 690-696. [CrossRef] [Google Scholar].

Cacace JE, Mazza G. 2006. Pressurized low polarity water extraction of lignans from whole flaxseed. J Food Eng 77(4): 1087-1095. [CrossRef] [Google Scholar].

Eliasson C, Kamal-Eldin A, Andersson R, Aman P. 2003. Highperformance liquid chromatographic analysis of secoisolariciresinol diglucoside and hydroxycinnamic acid glucosides in flaxseed by alkaline extraction. J Chromatogr A 1012(2): 151159. [CrossRef] [Google Scholar].

Herchi W, Arráez-Román D, Trabelsi H, Bouali I, Boukhchina S, Kallel H, Segura-Carretero A, Fernández-Gutierrez A. 2014. Phenolic compounds in flaxseed: a review of their properties and analytical methods. An overview of the last decade. J Oleo Sci 63 (1): 7-14. [Google Scholar] [CrossRef].

Ho CH, Cacace JE, Mazza G, 2007. Extraction of lignans, proteins and carbohydrates from flaxseed meal with pressurized low polarity water. LWT-Food Sci Technol 40(9): 1637-1647. [CrossRef] [Google Scholar].

Johnsson P, Kamal-Eldin A, Lundgren LN, Aman P. 2000. HPLC method for analysis of secoisolariciresinol diglucoside in flaxseeds. J Agr Food Chem 48(11): 5216-5219. [CrossRef] [Google Scholar].

Kajla P, Sharma A, Sood DR. 2015. Flaxseed - a potential functional food source. J Food Sci Technol 52(4): 1857-1871. [CrossRef] [Google Scholar].

Kanmaz EO. 2014. Subcritical water extraction of phenolic compounds from flaxseed meal sticks using accelerated solvent extractor (ASE). Eur Food Res Technol 238(1): 85-91. [Cross Ref] [Google Scholar].

Khattab RY, Zeitoun MA. 2013. Quality evaluation of flaxseed oil obtained by different extraction techniques. LWT-Food Sci Technol 53(1): 338-345. [Google Scholar] [Crossref].

Kaur P, Sharma P, Kumar V, Panghal A, Kaur J, Gat Y. 2017. Effect of addition of flaxseed flour on phytochemical, physicochemical, nutritional, and textural properties of cookies. J Saudi Society Agricult Sci in press. DOI: 10.1016/j.jssas.2017.12.004.

Kaur P, Waghmare R, Kumar V, Rasane P, Kaur S, Gat Y. 2018. Recent advances in utilization of flaxseed as potential source for value addition. $O C L$ 25(3): A304.

Long JJ, Fu YJ, Zu YG, Li J, Wang W, Gu CB, Luo M. 2011. Ultrasound-assisted extraction of flaxseed oil using immobilized enzymes. Bioresource Technol 102(21): 9991-9996. [Google Scholar] [CrossRef].

Malcolmson LJ, Przybylski R, Daun JK. 2000. Storage stability of milled flaxseed. J Am Oil Chem Soc 77(3): 235-238. [Google Scholar] [CrossRef].

Marpalle P, Sonawane SK, Arya SS. 2014. Effect of flaxseed flour addition on physicochemical and sensory properties of functional bread. LWT-Food Sci Technol 58(2): 614-619.

Marpalle P, Sonawane SK, LeBlanc JG, Arya SS. 2015. Nutritional characterization and oxidative stability of $\alpha$-linolenic acid in bread containing roasted ground flaxseed. LWT-Food Sci Technol 61(2): 510-515.

Morris DH. 2007. Flax: A health and nutrition primer. Flax Council of Canada. [BookRef].

Oomah BD. 2001. Flaxseed as a functional food source. J Sci Food Agri 81(9): 889-894. [Google Scholar] [CrossRef]. 
Piva GS, Weschenfelder TA, Franceschi E, Cansian RL, Paroul N, Steffens C. 2018. Extraction and modeling of flaxseed (Linnum usitatissimum) oil using subcritical propane. J Food Eng 228: 50-56. [Google Scholar] [CrossRef].

Pradhan RC, Meda V, Rout PK, Naik S, Dalai AK. 2010. Supercritical $\mathrm{CO}_{2}$ extraction of fatty oil from flaxseed and comparison with screw press expression and solvent extraction processes. J Food Eng 98(4): 393-397. [Google Scholar] [CrossRef].

Puri M, Sharma D, Barrow CJ. 2012. Enzyme-assisted extraction of bioactives from plants. Trends Biotechnol 30(1): 37-44. [Google Scholar] [CrossRef].

Rabetafika HN, Van Remoortel V, Danthine S, Paquot M, Blecker C. 2011. Flaxseed proteins: food uses and health benefits. Int J Food Sci Technol 46(2): 221-228. [Google Scholar] [CrossRef].

Renouard S, Hano C, Corbin C, Fliniaux O, Lopez T, Montguillon J, Barakzoy E, Mesnard F, Lamblin F, Lainé F. 2010. Cellulaseassisted release of secoisolariciresinol from extracts of flax (Linum usitatissimum) hulls and whole seeds. Food Chem 122(3): 679-687. [Google Scholar] [CrossRef].

Singh KK, Mridula D, Rehal J, Barnwal P. 2011. Flaxseed: a potential source of food, feed and fiber. Cri Rev Food Sci Nutri 51(3): 210-222. [Google Scholar] [CrossRef].

Tan ZJ, Wang CY, Yang ZZ, Yi YJ, Wang HY, Zhou WL, Li FF. 2015. Ionic liquid-based ultrasonic-assisted extraction of secoisolar- iciresinol diglucoside from flaxseed (Linum usitatissimum L.) with further purification by an aqueous two-phase system. Molecules 20(10): 17929-17943. [Google Scholar] [CrossRef].

Tan ZJ, Yang ZZ, Yi YJ, Wang HY, Zhou WL, Li FF, Wang CY. 2016. Extraction of oil from flaxseed (Linum usitatissimum L.) using enzyme-assisted three-phase partitioning. App Biochem Biotechnol 179(8): 1325-1335. [Google Scholar] [CrossRef].

Tehrani MHH, Batal R, Kamalinejad M, Mahbubi A. 2014. Extraction and purification of flaxseed proteins and studying their antibacterial activities. J Plant Sci 2(1): 70-76. [Google Scholar] [CrossRef].

Tirgar M, Silcock P, Carne A, Birch EJ. 2017. Effect of extraction method on functional properties of flaxseed protein concentrates. Food Chem 215: 417-424. [Google Scholar] [CrossRef].

Touré A, Xueming X. 2010. Flaxseed lignans: source, biosynthesis, metabolism, antioxidant activity, bio-active components, and health benefits. Comp Rev Food Sci F 9(3): 261-269. [Google Scholar] [CrossRef].

Zhang W, Xu S. 2007. Microwave-assisted extraction of secoisolariciresinol diglucoside from flaxseed hull. J Sci Food Agric 87(8): 1455-1462. [Google Scholar] [CrossRef].

Zhang ZS, Wang LJ, Li D, Jiao SS, Chen XD, Mao ZH. 2008. Ultrasound-assisted extraction of oil from flaxseed. Sep Purif Technol 62(1): 192-198. [Google Scholar] [CrossRef].

Cite this article as: Sharma M, Dadhwal K, Gat Y, Kumar V, Panghal A, Prasad R, Kaur S, Gat P. 2019. A review on newer techniques in extraction of oleaginous flaxseed constituents. OCL 26: 14. 